\title{
Examining the Relationships among Job Satisfaction, Organizational Commitment, and Turnover Intention: An Empirical Study
}

\author{
İlhami Yücel ${ }^{1}$ \\ ${ }^{1}$ Department of Management, Erzincan University, Erzincan, Turkey \\ Correspondence: İlhami Yücel, Faculty of Economic and Administrative Sciences, Department of Management, \\ Erzincan University, Erzincan, Turkey. Tel: 90-4-462-252-092. E-mail: yucelilhami@gmail.com
}

Received: July 22, 2012 Accepted: August 30, 2012 Online Published: October 16, 2012

doi:10.5539/ijbm.v7n20p44

URL: http://dx.doi.org/10.5539/ijbm.v7n20p44

\begin{abstract}
This study's aim is to examine the relationship among job satisfaction, organizational commitment, and turnover intention of employees. A model of job satisfaction, organizational commitment, and turnover intention is developed and tested in one field study. In this study, using a 250 employees of a Turkish manufacturing company, were given questionnaires to complete during regular working hours; 188 completed questionnaires were returned.. Job satisfaction, organizational commitment, and turnover intention are popular topics in the study of work related attitudes. The main objective of this article is to test the relationships among job satisfaction, organizational commitment and turnover intention. Structural equation modeling to test research hypotheses is used and the model that has high reliability and validity is developed. The results indicate that job satisfaction is one of the most antecedents of organizational commitment and turnover intention and suggest that high levels of job satisfaction results in higher commitment and lower turnover intention so job satisfaction positively influences on affective commitment, continuance commitment, and normative commitment while it is negatively impact on turnover intention. The results emphasize the need to consider the factors can be having effects on the relationship by highlighting to studies conducted on job satisfaction, organizational commitment, and turnover intention.
\end{abstract}

Keywords: job satisfaction, affective commitment, continuance commitment, normative commitment, turnover intention

\section{Introduction}

Job satisfaction, organizational commitment, and turnover intention are ones of the most examined popular subjects in the study of work related attitudes since the importance of organizational factors in affecting attitudes or behaviors of employees has attracted considerable attention on the organizational behavior area (Mathieu and Zajac, 1990; Meyer and Allen, 1984, 1990; O'Reilly and Chatman, 1986). In different studies, many researches and scholars examined the relationships among job satisfaction, organizational commitment, and turnover intention to see if there is any difference or not from the other studies, and to compare the differences if so. The majority of the studies suggested that job satisfaction has a significant and positive relationship with all dimensions of organizational commitment (Bagozzi, 1980; Reichers, 1985). Though the why and how question is still in question, organizational commitment and job satisfaction are jointed variables affecting negative outcomes such as turnover intention is clear (Shore and Martin, 1989).

Negative organizational outcomes such like turnover, absenteeism and turnover intention have attracted considerable interest from both managers and researchers across a wide array of disciplines. Based upon the literature, a structural model was tested in this study and the effects of job satisfaction and organizational commitment on turnover intention was tested. This study aims to investigate the impact of job satisfaction on all three dimensions of organizational commitment, and turnover intention and also the relationships between all the three commitments dimensions and turnover intention.

\section{Conceptual Framework and Model}

Increasingly, business and industrial concern are studying the job satisfaction, organizational commitment, and turnover intention. There is still much to learn about it, especially in terms of how it varies among different populations though job satisfaction has been thoroughly studied. To determine factors influencing job satisfaction 
allows leaders with necessary and meaningful information to make right decisions to increase employee job satisfaction (Cranny, Smith and Stone, 1992). Besides job satisfaction, increasing organizational commitment and decreasing turnover intention of employees are important issue for managers and organizations.

Because employees in organizations will either like or dislike their jobs, it is intuitive to suggest that, given the right conditions unique to the employee, some employees may stay or leave the organization (turnover). The study of job satisfaction attempts to explain this behavior and this is important from a humanitarian and utilitarian perspective (Spector, 1997). The humanitarian perspective suggests that people deserve to be treated fairly and appropriately, and the level of employee satisfaction or dissatisfaction may reflect the extent to which they experience good or bad treatment in an organization. It may also be indicative of the emotional and psychological wellbeing of the employees (Spector, 1997). The utilitarian perspective presupposes that the satisfaction or dissatisfaction of employees can lead to behaviors that affect the functioning of the organization (Spector, 1997). For example, increased productivity within the organization is a reflection of one of many positive outcomes of satisfied employees while absenteeism and sabotage are well established negative outcomes for disatisfied employees. Job satisfaction "is by far one of the most studied work attitudes by organizational behavior researchers" (Ghazzawi, 2008, p 1). Job satisfaction is "a pleasurable or positive emotional state resulting from the appraisal of one's job or job experiences" (Locke, 1993, p. 1300). Job satisfaction may be tested as part of the construct of employee involvement, as it is a combination of organizational commitment, intentions to stay (Ferguson, 2005). "The confusion, contradiction, and interchange of terms for engagement raise the question as to whether employee's engagement is a valid and reliable construct at all" (Ferguson, 2005). Turnover is defined as the "individual movement across the membership boundary of an organization" (Price, 2001: p. 600). The concept "individual" refers to the employees within an organization and the notion of movement can be interpreted either as an accession or a separation of the company. In turnover literature, authors also used other labels for turnover, such as quits, attrition, exits, mobility, migration or succession. A crude measurement of turnover would be (Morrell et. al, 2001: p. 10):

\section{$\frac{\text { Leavers in year }}{100 \text { Average number of employees during year }} \times 100$}

Turnover intention is defined as the mediating factor between attitudes affecting intent to quit and actually quitting an organization (Glissmeyer, Bishop, \& Fass, 2008). In a meta-analysis of the antecedents and correlates to employee turnover (Griffeth, Hom, \& Gaertner, 2000), intention to quit, job satisfaction, and organizational support were shown to be predictors of employee turnover. Mowday, Porter and Steers (1979) defined organizational commitment as a strong belief in the organization's goals and values and a willingness to exert considerable effort on behalf of the organization. Commitment to organization is linked to very important work-related factors: employee turnover, absenteeism and performance (Mowday, Steers \& Porter, 1979; Romzek, 1990). Organizational commitment is regularly conceptualized as an affective attachment to an organization as a consequence of an individual sharing the organization's values, their desire to remain in the organization, and their willingness to exert effort on behalf of the organization (Mowday, Steers, \& Porter, 1979). Previous examinations of commitment reveal that it deals with the individual's identification and involvement with an organization (Porter et al., 1974). When thought of this way, commitment is beyond passive loyalty, it involves an active relationship wherein individuals are willing to give of themselves to contribute to the organization's well being (Mowday et al., 1979). The most commonly accepted thoughts on commitment are that it is an indicator of employees who are strongly committed to an organization and are least likely to leave, hence it is a psychological state that binds an individual to an organization (Meyer, Allen, \& Gellatly, 1990). As a psychological state commitment is then characterized as an employees' relationship with the organizational and the decision the employee makes to continue membership in the organization (Meyer \& Allen, 1991). Committed employees are willing to go beyond the minimum requirements of their duties and are more likely to remain with the organization than uncommitted employees (Meyer \& Allen, 1997). In 1987, Meyer and Allen developed a commitment model with three measures of commitment that conform to previous researcher's conceptualization of commitment. The components were labeled affective commitment, continuance commitment, and normative commitment. Affective commitment refers to an employee's emotional attachment to, identification with, and involvement in the organization (Meyer \& Allen, 1997). Continuance commitment is so named because the employee feels the need to stay due to the potential loss of things such as benefits if they choose to leave and their lack of alternative employment and they are aware of the costs associated with leaving the organization (Allen \& Meyer, 1990; Meyer et al., 1990). Normative commitment reflects a feeling of obligation to remain with the organization. Employees have been taught through socialization that the organization expects their loyalty (Meyer \& Allen, 1991; Meyer et al., 1990). Research indicates employees with a strong sense of 
normative commitment positively correlate to work behaviors such as job performance, work attendance and organizational citizenship. They may not display the same enthusiasm or involvement as employees with affective commitment; however they may have an important impact on the way in which the work is accomplished (Meyer \& Allen, 1997). Research results have shown job dissatisfaction to be associated with negative behavioral outcomes such as absenteeism, workplace accidents, and labor turnover (Griffeth, Horn, \& Gaertner, 2000; Hellman, 1997; Hellriegel \& Slocum, 2004; Newstrom, 2006; Sousa-Poza \& Sousa-Poza, 2007). Currall et al., (2005) found pay satisfaction to be positively related to performance and negatively related to employee turnover intentions. Similarly, the results of another study by Davis (2006) also showed general job satisfaction to be strongly and negatively related to turnover intentions $(\mathrm{r}=-.69)$. Job satisfaction has been shown to be the main predictor of turnover intention (Larrabee, et al., 2003; Parry, 2008). Ding and Lin (2006) investigated the differences in job satisfaction and turnover intention between Taiwanese and U.S. hospital employees. They found that the negative direct effect of job satisfaction on turnover intentions and the indirect effect through organizational commitment are stronger for U.S. hospital employees than for Taiwanese hospital employees. Job satisfaction has important consequences for both organizations and their employees. Satisfied workers perform their jobs better (Judge, Thorensen, Bono, \& Patton, 2001), are less likely to engage in counterproductive behaviors (Chen \& Spector, 1992). Job satisfaction has been shown to be closely related to intentions to leave an organization (Chen \& Spector, 1992) and turnover intentions (Rusbult \& Farrell, 1983; Coomer \& Barriball, 2007). Job satisfaction also was shown to be associated with employee health and psychological well-being. In a meta-analysis, Hellman (1997) showed that the relationship between job satisfaction and intent to leave was significant and consistently negative. Hellman's findings support those of Price and Mueller, (1981) and Cavanagh and Coffin (1992), that increasing job satisfaction subsequently decreases rates of turnover intentions. Studies show that job satisfaction is related to satisfaction with life in general (Lance, Lautenschlage, Sloan, \& Varca 1989). Turnover intention among nurses has been shown to be influenced by work-related factors such as time pressure and quality of care, lack of autonomy, work schedule difficulties, and dissatisfaction with pay (Estryn-Behar, van der Heijden, Fry, \& Hasselhorn, 2010). Work-related social support also has been demonstrated to influence nurses' turnover intentions. Levels of commitment by nurses are associated with leaving the nursing profession altogether, as opposed to changing employers. Affective professional commitment and organizational commitment have also been found to be significantly related to intention to change professions for newly graduated nurses (Parry, 2008). For a long time, many scholars have made considerable research dedicated to developing useful models of job satisfaction, organizational commitment, voluntary turnover, and intent to quit among the most commonly proposed antecedents (Tett and Meyer, 1993). The basic objective of this article is to posit the relationships among job satisfaction, organizational commitment and turnover intention.

Figure 1 depicts the conceptual framework of relationships among job satisfaction, organizational commitment, and turnover intention.

\section{Organizational Commitment}

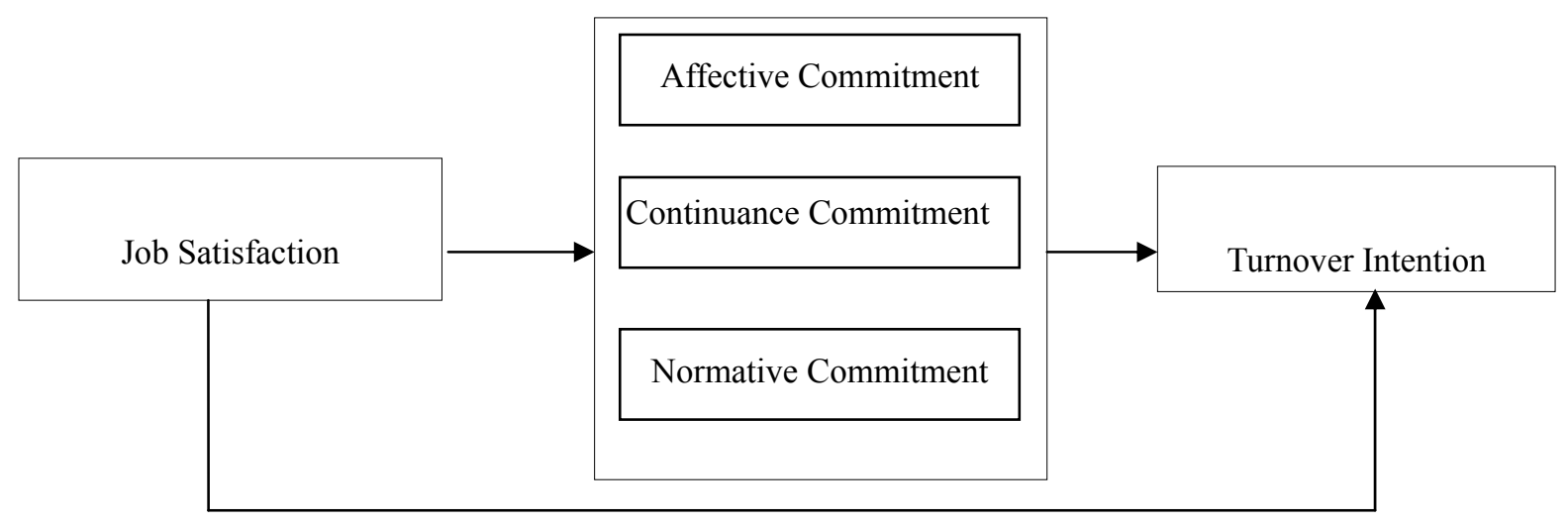

Figure 1. Relationship among job satisfaction, organizational commitment and turnover intention

The relationship between job satisfaction and organizational commitment can be seen from Figure 1. In Locke (1969, p.316)' study, job satisfaction is defined as "the pleasurable emotional state resulting from the 
achievement of one's job values. Job dissatisfaction is the unpleasurable emotional state resulting from the appraisal of one's job as frustrating or blocking the attainment of one's job values or as entailing disvalues. Job satisfaction and dissatisfaction are a function of the perceived relationship between what one wants from one's job and what one perceives it as offering or entailing". As stated by Robbins and Judge (2013), when people speak about employee attitude, they usually mean job satisfaction. Job satisfaction means having a positive feeling about a job, which is resulting from its characteristics. Job satisfaction is a highly important issue for organizational behavior researcher because a person with a high level of job satisfaction holds positive feeling about his or her job. However, a person with a low level of holds negative feelings (Robbins and Judge, 2013).

Irving, Coleman, and Cooper (1997) examined the relationship between affective, continuance, and normative commitment and job satisfaction. The study' sample had 232 employees as total participants included for the study. Their results showed that there was a significant and positive relationship between job satisfaction and both affective and normative commitment. However, the relationship between job satisfaction and continuance was negatively. In addition, turnover intentions have negative relationship with affective commitment, continuance commitment, and normative commitment, the strongest negative relationship is with continuance commitment.

Figure 1 shows the first part of model is related with the impact of job satisfaction on organizational commitment. It has been shown that organizational commitment is a strong predictor of a variety of organizational outcomes, including in-role and extra role performance and intended and actual turnover (Mathieu and Zajac, 1990; Meyer et. al., 2002). Meyer and Allen (1991) conceptualized organizational commitment in the three different approaches as affective, continuance, and normative commitment. According to Meyer and Allen (1991), these three dimensions of organizational commitment are distinguishable components of commitment.

Meyer and Allen (1991) stated that the three approaches have common point that commitment is a psychological state that (a) qualifies relationships between employee and their organization, and (b) has implications for the decision to stay or leave in the organization. These authors defined affective commitment, continuance commitment, and normative commitment as follows;

(a) Affective commitment refers to the extent to which employees identify with, are emotional attachment, and are involved in the organization. Employees having strong affective commitment stay with the organization because they want to.

(b) Continuance commitment refers to an employee's awareness costs of leaving the organization. Employees whose primary link to the organization is based on continuance commitment remain because they feel that have to so.

(c) Normative commitment reflects a feeling of obligation to remain in an organization. Employees with a high level of normative commitment feel that they ought to remain with the organization (Meyer and Allen, 1991). It develops as the result of a moral obligation to repay the organization for benefits (e.g., tuition payments or skills training) received from the organization or socialization experiences that emphasize the appropriateness of remaining loyal to one's employer.

Mowday, Porter and Steers (1982) defined organizational commitment as a strong belief in the organization's goals and values and a willingness to exert considerable effort on behalf of the organization. Organizational commitment is regularly conceptualized as an affective attachment to an organization as a consequence of an individual sharing the organization's values, their desire to remain in the organization, and their willingness to exert effort on behalf of the organization (Mowday et al., 1982). Such an attachment may be considered as emotional response demonstrating a strong desire to maintain membership in the organization (Testa, 2001). Previous examinations of commitment reveal that it deals with the individual's identification and involvement with an organization. When thought of this way, commitment is beyond passive loyalty, it involves an active relationship wherein individuals are willing to give of themselves to contribute to the organization's well-being (Mowday et al., 1982). The most commonly accepted thoughts on commitment are that it is an indicator of employees who are strongly committed to an organization and are least likely to leave; hence it is a psychological state that binds an individual to an organization. As a psychological state commitment is then characterized as an employees' relationship with the organizational and the decision the employee makes to continue membership in the organization (Meyer \& Allen, 1991). Committed employees are willing to go beyond the minimum requirements of their duties and are more likely to remain with the organization than uncommitted employees (Meyer \& Allen, 1991). O'Reilly and Chatman (1986) examined the underlying dimensions of commitment to the organization as a antecedents of extra-role performance and developed organizational commitment scale. The scale focused on three bases of psychological attachment to organizations, 
including (a) agreement associated with a certain benefit (b) identification associated with a need to be a member of the organization, and (c) internalization perceived as employee's values identification with the organization's values (Williams and Anderson, 1991).

Studies on organizational commitment have found different relationships with (a) job search behaviors, turnover intention, and extra-role behaviors and performance ; (b) job satisfaction and job tension; (c) autonomy and responsibility and role clarity; and (d) age, sex, education, career stage, need for achievement, and job tenure (Bateman and Strasser, 1984; Mathieu and Zajac, 1990). Accordingly, it is seen that organizational commitment is a predictor attracting researchers interested in behaviors of individuals in organizations (Chang, 1999). Based on the literature, the following research hypotheses are formulated:

Hypothesis 1: Job satisfaction is related to affective commitment of employee.

Hypothesis 2: Job satisfaction is related to continuance commitment of employee.

Hypothesis 3: Job satisfaction is related to normative commitment of employee.

Figure 1 shows a relationship between job satisfaction and turnover intention and the relationship was also studied in this study. Researchers examining the relationships between turnover intention and the other some factors affecting it have related a number of variables to turnover intention. These strongest variables are age, gender, tenure, education, available job alternatives, job content, and job satisfaction (Ghiselli, Lopa, and Bai, 2001). However, in this study, the relationship between job satisfaction and turnover intention was investigated. Turnover intention has been studied by many researchers. Mobley and colleagues suggested that turnover intention moderated the relationship between job satisfaction and turnover, and most researchers now accept the antecedent that intention to stay or leave in an organization for employees is the final cognitive step in the process of voluntary turnover (Steel and Ovalle, 1984). As a result, turnover intention has been incorporated in most turnover models developed in the past years (Lambert, Hogan and Barton, 2001). Fishbein and Ajzen's (1975: 369) stressed that "the best predictor of an individual's behavior will be measure of his intention to perform that behavior". Dalessio, Silverman, and Schuck (1986: 261) stressed the importance of turnover intention as follows: "In future research, more attention should be given to the direct and indirect influences of variables on intention to quit as opposed to the actual act of turnover. From employer standpoint, intention to quit may be a more important variable than the actual act of turnover. If the precursors to intention to quit are better understood, the employer could possibly institute changes to affect this intention. However, once an employee has quit, there is little the employer can do expect assume the expense of hiring and training another employee". According to Ghiselli, Lopa, and Bai (2001), the most important construct in attempting to understand turnover is job satisfaction. As stated by Hom and Griffeth (1995), the relationship between satisfaction and absenteeism is weaker than between job satisfaction and turnover intention. Thus, it is expected that turnover intention of employee is influenced directly by job satisfaction.

Hypothesis 4: Job satisfaction is negatively related to turnover intention of employee.

In this study, turnover intention was chosen because it is relevant for organizations and job satisfaction, and all dimensions of organizational commitment could be expected to negatively associate with it. Based on these, the following research hypotheses were formulated.

Hypothesis 5: Affective commitment is related to turnover intention of employee.

Hypothesis 6: Continuance commitment is related to turnover intention of employee.

Hypothesis 7: Normative commitment is related to turnover intention of employee.

\section{Methods}

\subsection{Sample and Data Collection}

This section addresses this study's methodology and data collection, which reinforce its unique aspects. In this study, to gain the data face to face questionnaire was applied. The original questionnaire was in English and was translated from English into Turkish by a bilingual speaker. The Turkish questionnaire was then given to another bilingual speaker to back-translate into English. In cases where the back-translation was not equivalent to the original version, the process of translation was repeated (Brislin, 1980). To develop the survey, a panel of two management scholars is asked to review the survey and provide feedback. Based on their feedback, the questionnaire was modified, and then pretested on 20 participants in an executive MBA class, which confirmed the reliability of our measures. As it is known, pre-testing of questionnaire is required before gathering data. Sekaran and Boguie (2010: 210) stated that "whether it is a structured interview where the questions are posed to the respondent in a predetermined order, or a questionnaire that is used in a survey, it is important to pretest the 
instrument to ensure that the questions are understood by the respondents and that are no problems with the wording or measurement. Pretesting involves the use of a small number of respondents to test the appropriateness of the questions and their comprehension". The participants, 250 employees of a Turkish manufacturing company, were given questionnaires to complete during regular working hours; however, the number of the employees who responded to the questionnaire is 188 . The response rate was $\% 75.2$.

\subsection{Measures}

\subsubsection{Job Satisfaction}

Job satisfaction was measured with five items taken from Brayfield-Rothe (1951) model of overall job satisfaction. These five items were "I fell fairly well satisfied with my present job," "Most days I am enthusiastic about my work," "Each day of work seems like it will never end" (reverse scored), "I find real enjoyment in my work," and "I consider my job rather unpleasant' (reverse scored), and ratings were obtained on a 5-point scale ranging from 1 (strongly disagree) to 5 (strongly agree). A global measure was selected since it is concerned with the broader domain of an individuals' satisfaction with his or her overall job, rather than with specific facets.

\subsubsection{Organizational Commitment}

A 12 -item measure of organizational commitment (Allen, \& Meyer, 1990, 1993) was used. This scale is designed to measure two dimensions of organizational commitment (affective commitment and continuance commitment). Participants responded to all items on a 5-point likert scale (1= "strongly disagree" to 5="strongly agree"). Sample items from each scale are: I would be very happy to spend the rest of my career with this organization" (affective commitment) and "If I leave the current organization, I might not find such good employment opportunities" (continuance commitment).

\subsubsection{Turnover Intention}

The questionnaire included three items measuring respondents' intention to quit their job. The items were adopted from Lance (1988) and Khatri, Fern, and Budhwar (2001). The total three items were presented to the respondents as a series of statements to which they were asked to indicate the extent to which they agree/disagree along a five-point Likert response scale $(1=$ strongly disagree, $5=$ strongly agree $)$.

\section{Results}

Findings of the research; socio-demographic features of the participants, reliability-validity analysis of the scales used was put forth via correlation analysis, t-test, and Structural Equation Modeling that is used to test research hypotheses.

\subsection{Socio-Demographic Features of the Employees}

Taking the distributions regarding the socio-demographical features of the participating employees into consideration, \% 32 of the total number of 188 employees was comprised of women, and $68 \%$ thereof was comprised of men, that the average age thereof was 35 , and average monthly wage thereof was TL 1,450. Taking the educational levels of the participants into consideration, it was found out that $21.2 \%$ thereof graduated from high-schools, $28.9 \%$ thereof from colleges, $36.2 \%$ thereof from faculties, and $7.2 \%$ thereof from master/doctorate degrees. Having examined the working periods thereof, average working period within the same company was found to be 8 year.

\subsection{Reliability-Validity Analysis of the Scales}

In this study, first of all, the reliability and validity of the job satisfaction, organizational commitment (affective commitment, continuance commitment, and normative commitment), and turnover intention scales were assessed. While Cronbach's Alpha Coefficient was used in the reliability analysis of the scales in use in the research, confirmatory factor analysis was used in the validity analysis thereof. Cronbach's Alpha Coefficient of the job satisfaction scale is .859 , and Cronbach's Alpha Coefficient of the affective commitment scale is .893 , for continuance commitment scale is .711 , and for normative commitment scale is .779 . Results of the validity analysis of the scales and all Cronbach's Alpha Coefficient are given below in Tables 1.

An indication of the stability and consistency with which the instrument measures the concept and helps to assess the "goodness" of measure is reliability of measure. In this study, internal consistency reliability of the scales was assessed. To assess the reliability of a summated scale where several items are summed to form a total score, internal consistency reliability is used. A popular approach to determine internal consistency reliability is the Coefficient alpha or Cronbach's alpha. This coefficient varies from 0 to 1 , and a value of 0.6 or less indicates unsatisfactory internal reliability (Malhotra, 2010). Cronbach's alpha coefficient is the most widely recommended measure of the reliability of a measurement scale with multipoint items. The higher the 
coefficients, the better the measuring instrument (Sekaran and Bougie, 2010). The results of job satisfaction, affective commitment, continuance commitment, normative commitment, and turnover intention scales reliability analysis were presented Table 1 .

After determining reliability, exploratory factor analysis was conducted to determine construct validity of job satisfaction, organizational commitment (affective, continuance, and normative), and turnover intention scales. Construct validity testifies to how well the results obtained from the use of the measure fit the theories around which the test is designed ((Sekaran and Bougie, 2010). Exploratory factor analysis (EFA) is designed for the situation where links between the observed and latent variables are unknown or uncertain (Bryne, 2010). Table 1 provides the results of validity analysis results.

Table 1 . The results of reliability and validity analyses

\begin{tabular}{|c|c|c|}
\hline & Factor Load & Cronbach's Alpha \\
\hline Job satisfaction (Brayfield and Rothe, 1951) & & 0.859 \\
\hline I consider my job rather unpleasant. & 0.721 & \\
\hline Each day of work seems like it will never end. & 0.741 & \\
\hline I feel fairly satisfied with my present job & 0.887 & \\
\hline Most days I am enthusiastic about my work & 0.658 & \\
\hline I find real enjoyment in my work & 0.801 & \\
\hline $\begin{array}{l}\text { Affective Commitment (Allen and Meyer, 1990; Meyer, Allen, and } \\
\text { Smith, 1993) }\end{array}$ & & 0.893 \\
\hline $\begin{array}{l}\text { I would be very happy to spend the rest of my career with this } \\
\text { organization. }\end{array}$ & 0.857 & \\
\hline I really feel as if this organization's problems are my own. & 0.873 & \\
\hline I feel like "part of the family" at my organization. & 0.823 & \\
\hline I feel "emotionally attached" to this organization. & 0.879 & \\
\hline $\begin{array}{l}\text { Continuance Commitment (Allen and Meyer, 1990; Meyer, Allen, } \\
\text { and Smith, 1993) }\end{array}$ & & 0.711 \\
\hline $\begin{array}{l}\text { Right now, staying with my organization is a matter of necessity as much } \\
\text { as desire. }\end{array}$ & 0.687 & \\
\hline $\begin{array}{l}\text { It would be very hard for me to leave my organization right now, even if } \\
\text { I wanted to. }\end{array}$ & 0.852 & \\
\hline $\begin{array}{l}\text { Too much of my life would be disrupted if I decided I wanted to leave } \\
\text { my organization nom. }\end{array}$ & 0.747 & \\
\hline $\begin{array}{l}\text { One of the few negative consequences of leaving this organization would } \\
\text { be the scarcity of available alternatives. }\end{array}$ & 0.636 & \\
\hline $\begin{array}{l}\text { Normative Commitment (Allen and Meyer, 1990; Meyer, Allen, and } \\
\text { Smith, 1993) }\end{array}$ & & 0.779 \\
\hline $\begin{array}{l}\text { Even it were to my advantage, I do not feel it would be right to leave my } \\
\text { organization now. }\end{array}$ & 0.783 & \\
\hline $\begin{array}{l}\text { I would not leave my organization right now because I have a sense of } \\
\text { obligation to the people in it. }\end{array}$ & 0.794 & \\
\hline I owe a great deal to my organization. & 0.735 & \\
\hline I would feel guilty if I left my organization now. & 0.792 & \\
\hline Turnover Intention (Lance, 1988; Khatri, Fern, and Budhwar, 2001) & & 0.846 \\
\hline I intend to leave the organization. & 0.858 & \\
\hline $\begin{array}{l}\text { I intent to make a genuine effort to find another job over the next few } \\
\text { months. }\end{array}$ & 0.920 & \\
\hline I often think about quitting. & 0.846 & \\
\hline
\end{tabular}

As it can be seen from Table 1, each scale has satisfactory reliability with Cronbach's Alpha above 0.60. Additionally the factor loads indicated the validity of scales is both above the acceptable lower limits. 
After that, to test the multi-dimensionality of job satisfaction, organizational commitment, and turnover intention, a confirmatory factor analysis by using structural equation modeling was conducted. A structural equations model (SEM) is like a multiple regression in that several variables are used to predict another variable. As it is known, SEM has some important advantage. The first advantage is that researcher can test at once all the interrelationships, and indirect, and direct paths, statistically controlling for all the others (Iacobucci and Churchill, 2010). It is a statistical analyze technique presenting confirmatory (i.e., hypothesis-testing) approach to the analysis of a structural theory bearing on some phenomenon, and typically, this theory offers "causal" processes (Byrne, 2010). SEM allows researchers to compare empirical data with a theoretical model, and this model has two major characteristics including (a) the estimation of multiple interrelated dependence relationship and (b) the ability to represent unobserved concepts in these relations, while accounting measurement error in the estimation (Terblanche and Boshoff, 2008).

In this path diagram, indicator variables were illustrated in rectangles while latent variables were shown in ovals. The relationships among job satisfaction, organizational commitment (affective, continual, and normative commitment), and turnover intention can be seen from Figure 2.

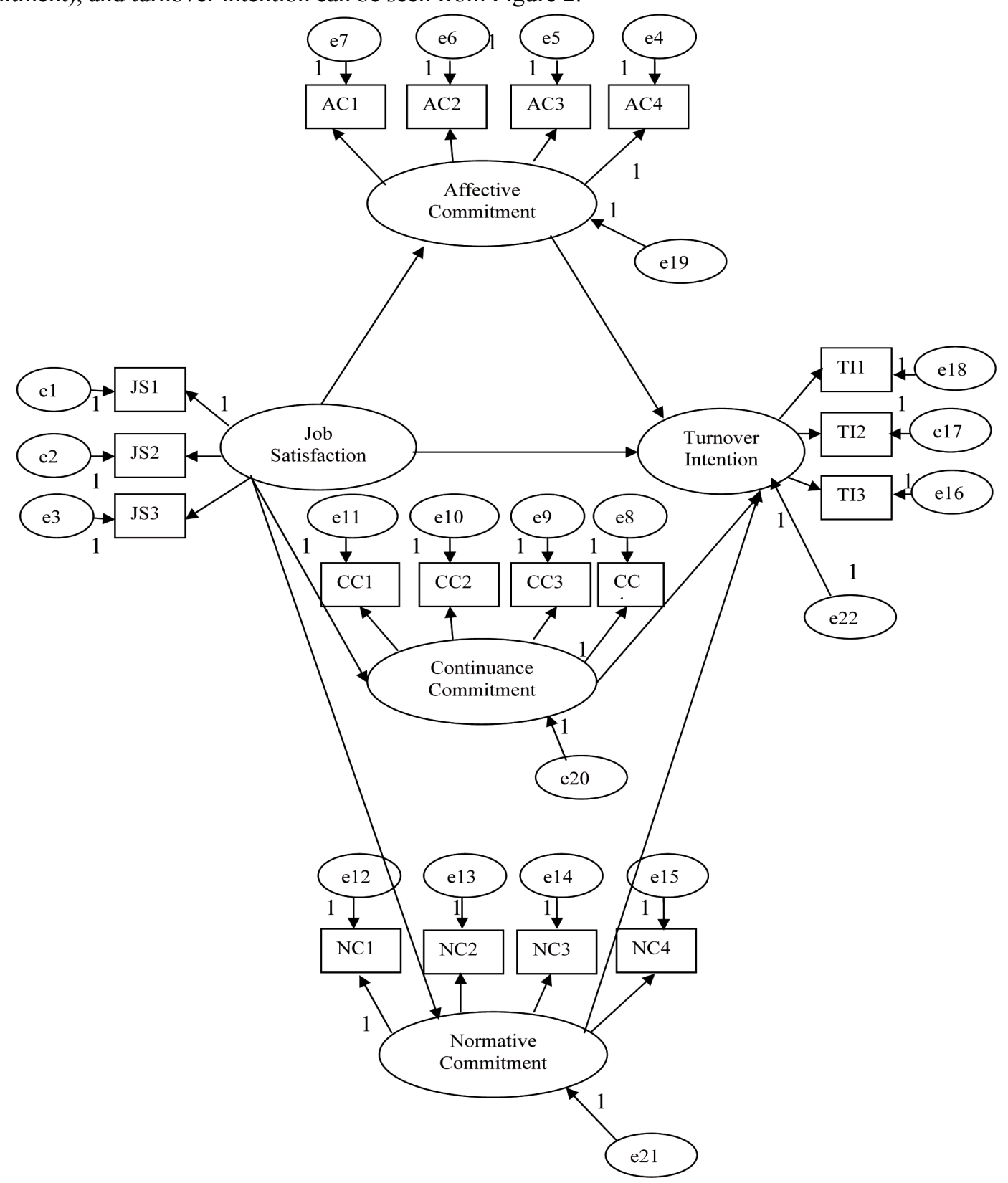

Figure 2. Model of the relationships among job satisfaction, organizational commitment, and turnover intention 
As mentioned before, to test research hypotheses Structural Equation Modeling was used. The variables that were used in the model were presented Table 2.

Table 2. The summary of variables in the model

\begin{tabular}{ll}
\hline Number of Variables In Your Model: & 45 \\
\hline Number of Observed Variables & 18 \\
Number of Unobserved Variables & 27 \\
Number of Exogenous Variables & 23 \\
Number of Endogenous Variables & 22 \\
\hline
\end{tabular}

The number of total variables in the model was 45. Eighteen of them were the observed variables while 27 of them were the unobserved variables. The model included 23 exogenous variables and 22 endogenous variables in sum.

The details of overall model fit criteria between the model and the data (goodness of fit criteria) were depicted Table 3.

Table 3. Fit measures

\begin{tabular}{lccc}
\hline Fit Measures & Measurement Model & Ideal Model & \\
\hline Discrepancy $\left(^{2}\right)$ & 273.696 & 0.000 & CMIN \\
Degrees of freedom & 128 & 0 & DF \\
$\mathrm{P}$ & 0.000 & & $\mathrm{P}$ \\
Discrepancy / df $\left({ }^{2} / \mathrm{df}\right)$ & 2.138 & & CMINDF \\
Goodness of Fit Index & 0.866 & 1.000 & GFI \\
Adjusted GFI & 0.821 & & AGFI \\
Normed Fit Index & 0.835 & 1.000 & NFI \\
Relative Fit Index & 0.802 & & RFI \\
Incremental Fit Index & 0.905 & & IFI \\
Tucker-Lewis Index & 0.884 & 1.000 & TLI \\
Comparative Fit Index & 0.903 & & CFI \\
RMSEA & 0.078 & & RMSEA \\
Hoelter .05 Index & 107 & & HFIVE \\
Hoelter .01 Index & 115 & & HONE \\
\hline
\end{tabular}

In Table 3, the details of overall model fit criteria between the model and the data (goodness of fit criteria) were presented. In evaluating the goodness-of-fit between the model and the data the first measure is the likelihood ratio chi-square statistics. This value has a statistical significance $(\mathrm{p}=0.000)$. Dividing Chi-Square into degrees of freedom value is $\chi 2$ index which has to be between 2 and 3 for good fit of model. In this research, Discrepancy / df $(2 / \mathrm{df})$ was found 2.138. Chi-Square/df represents the fitness between the model and data. Given the known sensitivity of this statistic to sample size, however, use of the $\chi 2$ index provides little guidance in determining the extent to which the model does not fit. Thus, it is more reasonable and appropriate to base decisions on other indices of fit (Byrne, 2010). Therefore, it is necessary to look at other goodness of-fit indices in order to evaluate the fitness between the model and the data.

Goodness of Fit Index (GFI) is another index to assess the fitness between the data and model. GFI, Comparative Fit Index (CFI), Normed Fit Index (NFI), Tucker-Lewis Index (TLI), Relative Fit Index (RFI), and Incremental Fit Index (IFI) are all considered as fit indexes. These fit indexes take a value between the range of " 0 " and "1." The range of values for this pair of approximate fit indexes is generally $0-1.0$ where 1.0 indicates the best fit 
(Kline, 2011). As it can be seen form Table 3, the value of GFI is 0.866 , which is close to one. Thus, it can be concluded that there is a perfect fit between the data and the model. In addition to GFI, AGFI (0.821), NFI (0.835), RFI (0.802), IFI (0.905), TLI (0.884) and CFI (0.930) represented that there was fitness between the data and the model. Root Mean Square Error of Approximation (RMSEA) is also used to evalute the fitness between the model and data. Values ranging from 0.05 to 0.08 are deemed acceptable. (Hair et al.; 1998) RMSEA is 0.078 and it represented a good fit value.

Hoelter's critical sample size that focuses directly on the adequacy of the sample size, rather than on model fit (Byrne, 2010), and gives the significant minimum sample size depending on the sample size and variable number at the analysis. Hoelter .05 represents the required minimum sample size to test the hypothesis at $95 \%$ confidence interval level and 0.05 significance level and Hoelter .01 represents the required minimum sample size to test the hypothesis at $99 \%$ confidence interval level and 0.01 significance level. In this study, sample size (188) is larger than required minimum sample sizes which is obtained as a result of Hoelter .05 (107) and Hoelter .01 (115) indexes. Unstandardized regression coefficients of job satisfaction, affective commitment, continuance commitment, normative commitment, and turnover intention can be seen form Table 4 .

Table 4. Unstandardized regression coefficients

\begin{tabular}{|c|c|c|c|c|c|}
\hline & & Estimate & Std. Error & t- value & $\mathbf{P}$. \\
\hline Continuance Commitment & $<---$ Job Satisfaction & .208 & .060 & 3.473 & 0.000 \\
\hline Affective Commitment & $<---$ Job Satisfaction & .723 & .086 & 8.445 & 0.000 \\
\hline Normative Commitment & $<---$ Job Satisfaction & .493 & .081 & 6.119 & 0.000 \\
\hline Turnover Intention & $<---$ Job Satisfaction & -.391 & .154 & -2.540 & .011 \\
\hline Turnover Intention & $<---$ Affective Commitment & -.077 & .124 & -.623 & .533 \\
\hline Turnover Intention & $<---$ Continuance Commitment & -.104 & .159 & -.652 & .514 \\
\hline Turnover Intention & $<---$ Normative Commitment & .108 & .173 & .622 & .534 \\
\hline JS1 & $<---$ Job Satisfaction & 1.000 & & & \\
\hline JS2 & $<---$ Job Satisfaction & .982 &, 083 & 11.873 & 0.000 \\
\hline JS3 & $<---$ Job Satisfaction & .928 & ,082 & 11.338 & 0.000 \\
\hline $\mathrm{AC} 4$ & $<---$ Affective Commitment & 1.000 & & & \\
\hline $\mathrm{AC} 3$ & $<---$ Affective Commitment & 1.101 & .081 & 13.517 & 0.000 \\
\hline $\mathrm{AC} 2$ & $<---$ Affective Commitment & 1.009 & .078 & 13.009 & 0.000 \\
\hline $\mathrm{AC} 1$ & $<---$ Affective Commitment & 1.030 & .082 & 12.503 & 0.000 \\
\hline $\mathrm{CC} 4$ & $<---$ Continuance Commitment & 1.000 & & & \\
\hline $\mathrm{CC} 3$ & $<---$ Continuance Commitment & 1.314 & .213 & 6.171 & 0.000 \\
\hline $\mathrm{CC} 2$ & $<---$ Continuance Commitment & 1.943 & .307 & 6.324 & 0.000 \\
\hline $\mathrm{CC} 1$ & $<---$ Continuance Commitment & .747 & .178 & 4.192 & 0.000 \\
\hline NN1 & $<---$ Normative Commitment & 1.000 & & & \\
\hline NN2 & $<---$ Normative Commitment & 1.097 & .142 & 7.724 & 0.000 \\
\hline NN3 & $<---$ Normative Commitment & 1.052 & .146 & 7.202 & 0.000 \\
\hline NN4 & $<---$ Normative Commitment & 1.208 & .156 & 7.762 & 0.000 \\
\hline TI3 & $<---$ Turnover Intention & 1.000 & & & 0.000 \\
\hline TI2 & $<---$ Turnover Intention & 1.084 & .116 & 9.380 & 0.000 \\
\hline TI1 & $<---$ Turnover Intention & .770 & .093 & 8.283 & 0.000 \\
\hline
\end{tabular}


The statistical significance of each estimated parameter is assessed by its t-value (Sharma, 1996). From Table 4, job satisfaction has a positive effect on affective commitment, continuance commitment, and normative commitment. In other words, job satisfaction has an influence on the affective commitment, continuance commitment, and normative commitment at the significance level of $\alpha=0.01$. On the other hand, job satisfaction has a negative influence on the affective commitment, continuance commitment, and normative commitment. Organization should try to increase job satisfaction of employees. As it can be understood from Table 4, there is a positive relationship between job satisfaction and organizational commitment. However, there is a negative relationship between job satisfaction and turnover intention.

The standardized regression coefficients were presented in Table 5. The standardized regression coefficients allow the researcher to compare directly the relative effect of each independent variable on the dependent variable (Hair et al., 1998). As it can be seen from Table 5, the standardized regression coefficients had values ranging .532 and .952. It means that the variables used to explain job satisfaction, affective commitment, continual commitment, normative commitment, and turnover intention had impact on these dimensions in differing degrees.

Table 5. Standardized regression coefficients

\begin{tabular}{|c|c|c|c|}
\hline & & & Estimate \\
\hline Continuance Commitment & $<---$ & Job Satisfaction & .320 \\
\hline Affective Commitment & $<---$ & Job Satisfaction & .677 \\
\hline Normative Commitment & $<---$ & Job Satisfaction & .595 \\
\hline Turnover Intention & $<---$ & Job Satisfaction & -.364 \\
\hline Turnover Intention & $<---$ & Affective Commitment & -.077 \\
\hline Turnover Intention & $<---$ & Continuance Commitment & -.063 \\
\hline Turnover Intention & $<---$ & Normative Commitment & .083 \\
\hline JS1 & $<---$ & Job Satisfaction & .843 \\
\hline JS2 & $<---$ & Job Satisfaction & .807 \\
\hline JS3 & $<---$ & Job Satisfaction & .765 \\
\hline $\mathrm{AC} 4$ & $<---$ & Affective Commitment & .841 \\
\hline $\mathrm{AC} 3$ & $<---$ & Affective Commitment & .840 \\
\hline $\mathrm{AC} 2$ & $<---$ & Affective Commitment & .815 \\
\hline $\mathrm{AC} 1$ & $<---$ & Affective Commitment & .799 \\
\hline $\mathrm{CC} 4$ & $<---$ & Continuance Commitment & .532 \\
\hline $\mathrm{CC} 3$ & $<---$ & Continuance Commitment & .594 \\
\hline $\mathrm{CC} 2$ & $<---$ & Continuance Commitment & .952 \\
\hline $\mathrm{CC} 1$ & $<---$ & Continuance Commitment & .569 \\
\hline NN1 & $<---$ & Normative Commitment & .681 \\
\hline NN2 & $<---$ & Normative Commitment & .698 \\
\hline NN3 & $<---$ & Normative Commitment & .648 \\
\hline NN4 & $<---$ & Normative Commitment & .719 \\
\hline TI3 & $<---$ & Turnover Intention & .799 \\
\hline TI2 & $<---$ & Turnover Intention & .866 \\
\hline TI1 & $<---$ & Turnover Intention & .634 \\
\hline
\end{tabular}




\section{Conclusion and Implications}

Job satisfaction is thought to influence their work outcomes such as organizational commitment and turnover intentions. In the current study, it is identified the potential relationships of job satisfaction, organizational commitment, and turnover intentions. In addition, our findings suggest that organizations be aware of organizational commitment and turnover intentions among employees who vary in job satisfaction levels. The objective of this study was to determine the among job satisfaction, organizational commitment (affective commitment, continuance commitment, and normative commitment, and turnover intention. First of all, the reliability and validity of the scale was assessed using Cronbach's Alpha and exploratory factor analysis. It can be seen that the model, which is developed to examine the relationships job satisfaction, affective commitment, continuance commitment, normative commitment, and turnover intention is valid and reliable. The detailed results of the analyses reveal the fact that job satisfaction is positively impact on affective commitment, continuance commitment, and normative commitment. Another important result of this analysis is that there is a negative relationship between job satisfaction and turnover intention. In other words, it was found in this study that job satisfaction is one of the most important antecedents of organizational commitment and turnover intention of employees. Within this context of managing organizational behavior, the results of the present study have a number or practical implications. Especially, the job satisfaction's of employees is important issue. The effectiveness of selection, training, and supervisory programs should be gauged in part by their effect on employees' satisfaction with their work. Managers should try to increase of job satisfaction of employees. As in most studies, this research has limitations that need to be considered. Limitation stems from our sample, which was drawn from a single organization located in a specific geographic location and was also one-source bias. For further research can be included different organizations and sectors. For further research, some other various antecedents can be included into this reliable and valid research model that examines the employees' turnover intention. Additionally, next studies may examine the moderators and mediators can have some effects on relationships among job satisfaction, organizational commitment, and turnover intentions. Findings of this study would help managers and policy makers of companies as well as practitioners to formulate strategies and program to overcome turnover problem among employees as well as to ensure organizational commitment and job satisfaction. Consequently, the study claims that who give decisions for organizations should consider some aspects that have been identified to be related and have affected job satisfaction, organizational commitment, and turnover intentions.

\section{References}

Allen, N. J., \& Meyer, J. P. (1990). The Measurement and Antecedents of Affective, Continuance and Normative Commitment to the Organization. Journal of Occupational Psychology, 63(1), 1-18. http://dx.doi.org/10.1111/j.2044-8325.1990.tb00506.x

Bagozzi, R. P. (1980). Performance and Satisfaction in an Industrial Sales Forces: An Examination of Their Antecedents and Simultaneity. Journal of Marketing, 15(4), 65-67. http://dx.doi.org/10.2307/1249978

Bateman, T., \& Strasser, S. (1984). A Longitudinal Analysis of the Antecedents of Organizational Commitment. Academy of Management Journal, 77, 95-112. http://dx.doi.org/10.2307/255959

Brayfield, A. H., \& Rothe, H. F. (1951). An Index of Job Satisfaction. Journal of Applied Psychology, 35(5), 307-311. http://dx.doi.org/10.1037/h0055617

Byrne, B. (2010). Structural Equation Modeling with EQS: Basic Concepts, Applications and Programming (2nd Ed.). UK: Routhledge Taylor \& Francis Group.

Cavanagh, S., \& Coffin, D. (1992). Staff turnover among hospital nurses. Journal of Advanced Nursing, 17, 1369-1376. http://dx.doi.org/10.1111/j.1365-2648.1992.tb01861.x

Chang, E. (1999). Career Commitment as a Complex Moderator of Organizational Commitment and Turnover Intention. Human Relations, 52(10), 1257-1278. http://dx.doi.org/10.1177/001872679905201002

Chen, P. Y., \& Spector, P. E. (1991). Negative affectivity as the underlying cause of correlations between stressors and strains. Journal of Applied Psychology, 76(3), 398-407. http://dx.doi.org/10.1037/0021-9010.76.3.398

Coomber, B., \& Barriball, K. L. (2007). Impact of job satisfaction components on intent to leave and turnover for hospital-based nurses: A review of the research literature. International Journal of Nursing Studies, 44(2), 297-314. http://dx.doi.org/10.1016/j.ijnurstu.2006.02.004 
Cranny, C., Smith, P., \& Stone, E. (1992). Job Satisfaction: How People Feel about Their Jobs and How It Affects Their Performance. New York: Wiley.

Currall, S. C., Towler, A. J., Judge T. A., \& Kohn, L. (2005). Pay Satisfaction and Organizational Outcomes. Personnel Psychology, 58(3), 613-640. http://dx.doi.org/10.1111/j.1744-6570.2005.00245.x

Dallesio, A., Silverman, W., \& Schuck, J. (1986). Pats to Turnover: A Re-Analysis and Review of Existing Data on the Mobley, Horner, and Hollingsworth's Turnover Model. Human Relations, 39(2), 245-264.

Davis, P. J. (2006). In search of the common wealth: A service-profit chain for the public sector. International Journal of Productivity and Performance Management, 55(2), 163-172. http://dx.doi.org/10.1108/17410400610641735

Ding, C. G., \& Lin, C. P. (2006). Comparing the effects of determinants of turnover intentions between Taiwanese and U.S. hospital employees. Human Resource Development Quarterly, 17(4), 403-421. http://dx.doi.org/10.1002/hrdq.1183

Estryn-Behar, M., van der Heijden, B. I., Fry, C., \& Hasselhorn, H. M. (2010). Longitudinal analysis of personal and work-related factors associated with turnover among nurses. Nursing Research, 59(3), 166-177. http://dx.doi.org/10.1097/NNR.0b013e3181dbb29f

Ferguson, A. (2005). Employee Engagement: Does it exist, and if so, how does it relate to performance and other job constructs such as commitment? Annual Industrial/ Organisational Psychology Conference Australian Psychological Society, 3-19.

Fishbein, M., \& Ajzen, I. (1975). Belief, Attitude, Intention and Behavior: An Introduction to Theory and Research, Reading. MA: Addisson-Wesley.

Ghazzawi, I. (2008). Job satisfaction antecedents and consequences: a new conceptual framework and research agenda. The Business Review, 11, 1-11.

Ghiselli, F. R., Lopa, L. J., \& Bai, B. (2001). Job Satisfaction, Life Satisfaction, and Turnover Intent. Cornell Hotel and Restaurant Administration Quarterly, 42(2), 28-37.

Glissmeyer, M., Bishop J. W., \& Fass, R. D. (2008). Role conflict, role ambiguity and intention to quit the organization: The case of law enforcement. Academy of Management Journal, 40(1), 82-111.

Griffeth, R. W., Hom, P. W., \& Gaertner, S. (2000). A meta-analysis of antecedents and correlates of employee turnover: Update, moderator tests, and research implications for the next millennium. Journal of Management, 26, 463-488. http://dx.doi.org/10.1177/014920630002600305

Hair, J., Anderson, R., Tatham, R., \& Black, W. (1998). Multivariate Data Analysis with Readings (5th Ed.). Prentice- Hall International, Inc.

Hellman, C. M. (1997). Job satisfaction and intent to leave. Journal of Social Psychology, 137(6), 667-689. http://dx.doi.org/10.1080/00224549709595491

Hellriegel, D., \& Slocum, J. W. (2004). Organizational behavior. Thomson, South-Western.

Hom, P., \& Griffeth, R. (1995). Employee Turnover. Ohio: South-Western Publishing.

Iacobucci, D., \& Churchill, A. G. (2010). Marketing Research Methodological Foundations (10th Ed.). South-Western Cengage Learning.

Irving, P., Coleman, D., \& Cooper, C. (1997). Further Assessments of a Three-Component Model of Occupational Commitment: Generalizability and Differences across Occupations. Journal of Applied Psychology, 82(3), 444-452. http://dx.doi.org/10.1037/0021-9010.82.3.444

Judge, T. A., Thoresen, C. J., Bono, J. E., \& Patton, G. K. (2001). The job satisfaction-job performance relationship: A qualitative and quantitative review. Psychological Bulletin, 127, 376-407. http://dx.doi.org/10.1037/0033-2909.127.3.376

Lambert, E. G., Hogan, N. L., \& Barton, M. S. (2001). The Impact of Job Satisfaction on Turnover Intent: A Test of a Structural Model Using a National sample of Workers. The Social Science Journal, 38(2), 233-250. http://dx.doi.org/10.1016/S0362-3319(01)00110-0

Lance, C. E., Lautenschlager, G. T., Sloan, C. E., \& Varca, P. E. (1989). A comparison between bottom-up, top-down and bi-directional models of relationships between global and life facet satisfaction. Journal of Personality, 57, 601-624. http://dx.doi.org/10.1111/j.1467-6494.1989.tb00565.x 
Larrabee, J. H., Janney, M. A., Ostrow, C. L., Withrow, M. L., Hobbs, G. R., \& Burant, C. (2003). Predicting registered nurse job satisfaction and intent to leave. Journal of Nursing Administration, 33, 271-283. http://dx.doi.org/10.1097/00005110-200305000-00003

Locke, E. A. (1969). What is Job Satisfaction. Organizational Behavior and Human Performance, 4(November), 309-336. http://dx.doi.org/10.1016/0030-5073(69)90013-0

Locke, E. A. (1976). The nature and causes of job satisfaction. In M. D. Dunnette (Ed.), Handbook of industrial and organizational psychology (pp. 1297-1349). Chicago: Rand McNally.

Locke, J. (1993). A child's path to spoken language. Cambridge, MA: Harvard University Press.

Malhotra, N. (2010). Marketing Research: an applied orientation (6th ed.). Boston: Pearson Education.

Mathieu, J. E., \& Zajac, D. M. (1990). A Review and Meta-Analysis of the Antecedents, Correlates, and Consequences of Organizational Commitment. Psychological Bulletin, 108(2), 171-194. http://dx.doi.org/10.1037/0033-2909.108.2.171

Meyer, J. P., Allen, N. J., \& Smith, C. (1993). Commitment to Organizations and Occupations: Extension and Test of a Three-Component Conceptualization. Journal of Applied Psychology, 78, 538-551. http://dx.doi.org/10.1037/0021-9010.78.4.538

Meyer, J. P., \& Allen, N. J. (1991). A Three-Component Conceptualization of Organizational Commitment. Human Resource Management Review, 1(1), 61-89. http://dx.doi.org/10.1016/1053-4822(91)90011-Z

Meyer, J. P., Stanley, D. J., Herscovitch, L., \& Topolnytsky, L. (2002). Affective, Continuance and Normative Commitment to the Organization: A Meta-Analysis of Antecedents, Correlates, and Consequences. Journal of Vocational Behavior, 61, 20-52. http://dx.doi.org/10.1006/jvbe.2001.1842

Meyer, J., \& Allen, N (1984). Testing the 'Side-Bet Theory' of Organizational Commitment: Some Methodological Considerations. Journal of Applied Psychology, 69, 372-378. http://dx.doi.org/10.1037/0021-9010.69.3.372

Meyer, J., \& Allen, N. (1997). Commitment in the workplace. Thousand Oaks, CA: SAGE Publications.

Meyer, J., Allen, N., \& Gellatly, I. (1990). Affective and continuance commitment to the organization: Evaluation of concurrent and time-lagged relations. Journal of Applied Psychology, 75, 710-720. http://dx.doi.org/10.1037/0021-9010.75.6.710

Morrell, K., Loan-Clarke, J., \& Wilkinson, A. (2001). Unweaving Leaving: The Use of Models in theManagement of Turnover. International Journal of Management Reviews, 3(3), 219-244. http://dx.doi.org/10.1111/1468-2370.00065

Mowday, R., Porter, L., \& Steers, R. (1982). Organizational Linkages: The Psychology of Commitment, Absenteeism, and Turnover. New York: Academic Press.

Newstrom, J. W. (2007). Organizational behavior: Human behavior at work (12th ed.). New York, NY: McGraw-Hill/Irwin.

O’Reilly, C. III., \& Chatman, J. (1986). Organizational Commitment and Psychological Attachment: The Effects of Compliance, Identification, and Internalization on Prosocial Behavior. Journal of Applied Psychology, 71, 492-499. http://dx.doi.org/10.1037/0021-9010.71.3.492

Parry, J. (2008). Intention to leave the profession: antecedents and role in nurse turnover", Journal of Advanced Nursing, 64(2), 157-67. http://dx.doi.org/10.1111/j.1365-2648.2008.04771.x

Price, J. 1. (2001). Reflections on the determinants of voluntary turnover. International Journal of Manpower, 22(7), 660-624. http://dx.doi.org/10.1108/EUM0000000006233

Price, J. L., \& Mueller, C. W. (1981). A causal model of turnover for nurses. Academy of Management Journal, 24, 543-563. http://dx.doi.org/10.2307/255574

Reichers, A. E. (1985). A Review and Reconceptualization of Organizational Commitment. Academy of Management, 10, 465-476.

Robbins, P. S., \& Judge, A. T. (2013). Organizational Behavior (15th Ed.). New Jersey: Pearson Prentice Hall.

Romzek, B. (1990). Employee Investment and Commitment: The Ties that Bind. Public Administration Review, 50, 374-82. http://dx.doi.org/10.2307/976619

Rusbult, C., \& Farrell, D. (1983). A longitudinal test of the investment model: The impact on job satisfaction, job 
commitment, and turnover of variations in rewards, costs, alternatives, and investments. Journal of Applied Psychology, 68(3). http://dx.doi.org/10.1037/0021-9010.68.3.429

Schore, L. M., \& Martin, H. J. (1989). Job Satisfaction and Organizational Commitment in Relation to Work Performance and Turnover Intentions. Human Relations, 42, 625-638. http://dx.doi.org/10.1177/001872678904200705

Sekaran, U., \& Bougie, R. (2010). Research Methods for Business: A Skill Building Approach (15th Ed.). Chichester: John Willey \& Sons Ltd.

Sharma, S. (1996). Applied Multivariate Techniques. New York: John Wiley Sons Inc.

Sousa-Poza, A., \& Sousa-Poza, A. A. (2007). The Effect of Job Satisfaction on Labor Turnover by Gender: An Analysis for Switzerland. Journal of Socio-Economics, 36(6), 895-913. http://dx.doi.org/10.1016/j.socec.2007.01.022

Spector, P. E. (1997). Job satisfaction: Application, assessment, causes, and consequences. London: Sage.

Steel, R., \& Ovalle, N. (1984). A Review and Meta-Analysis of Research on the Relationship between Behavioral Intentions and Employee Turnover. Journal of Applied Psychology, 69(4), 673-686. http://dx.doi.org/10.1037/0021-9010.69.4.673

Terblanche, N. S., \& Boshoff, C. (2008). Improved Scale Development in Marketing. International Journal of Marketing Research, 50(1), 105-119.

Testa, M. R. (2001). Organizational Commitment, Job Satisfaction, and Effort in the Service Environment. The Journal of Psychology, 135(2), 226-236. http://dx.doi.org/10.1080/00223980109603693

Tett, R. P., \& Meyer, J. P. (1993). Job Satisfaction, Organizational Commitment, Turnover Intention, and Turnover: Path Analyses Based on Meta-Analytic Findings. Personnel Psychology, 46, 259-293. http://dx.doi.org/10.1111/j.1744-6570.1993.tb00874.x

Williams, L. J., \& Anderson, S. E. (1991). Job Satisfaction and Organizational Commitment as Predictors of Organizational Citizenship and In-Role Behaviors. Journal of Management, 17(3), 601-617. http://dx.doi.org/10.1177/014920639101700305 